
ЗБЕРЕЖЕННЯ ТРАДИЦІЙ УКРАЇНСБКОГО ХОРОВОГО МИСТЕЦТВА

J. Brown // Medical Education. - 2007. - Vol. 42 (3). pp. 271-278.

5. Dornan T. O. Apprenticeship and the "New Medical Education" / T. Dornan // Journal of the Royal Society of Medicine. - 2005. - Vol. 9(3). - pp.91-95 [Електронний ресурс]. - Режим доступу: https:// www.ncbi.nlm.nih.gov/pmc/articles/PMC1079407/ . Назва з екрану.

6. General Medical Council. Tomorrow's Doctors Recommendations on

7. Health and Medicine in Medieval England / Learning History Site. [Електронний ресурс]. Режим достуny: http://www. historylearningsite. co.uk/health_and medicine in medieval .htm .-Назва з екрану.

8. Kopelman P. The Future of UK Medical Education Curriculum - What Type of Medical Graduates Do We Need? / Peter Kopelman // Future Hospital Journal. 2014. - Vol. 1. - No 1. - pp.41-46.
9. Medical Education in 1858 [Електронний pecypc]. - Режим достуnу: http://www.thornber.net/ medicine/html/scimedph.html. - Назва з екрану.

10. Reinarz J. Towards a History of Medical Education in Provincial England / J. Reinarz [Електронний ресурс]. - Режим доступу: http:// www.evolve 360. co.uk/data/10/docs/17/17reinarz.pdf. - Назва з екрану.

11. Report of the Royal Commission on Medical Education 1965-1968. - London: HMSO, 1968. $302 \mathrm{p}$.

12. Rivlin J. J. Getting a Medical Qualification in England in the Nineteenth Century / J. J. Rivlin [Електронний ресурс]. - Режим доступу: http:// www.evolve360.co.uk/data/10/docs/09/09rivlin.pdf. Назва з екрану.

13. Smith R. Medical Discipline: the Professional Conduct of the GMC 1858 - 1990 / Russell G. Smith. Oxford: Oxford University Press, 1994. - 117 p.

Стаття надійшла до редакції 28.12.2017

УДК 7.071.2

Світлана Теодорович, викладач кафедри музикознавства та хорового мистецтвва Михайло Ковбасюк, доцент кафедри музикознавства та хорового мистецтва факультету культури і мистеитв Львівського національного університету імені Івана Франка

\title{
ПСИХОЛОГІЧНА ЗРІЛІСТЬ ДИРИГЕНТА-ХОРМЕЙСТЕРА ЯК ВАЖЛИВА ЗАПОРУКА ЗБЕРЕЖЕННЯ ТРАДИЦЙ УКРАЇНСЬКОГО ХОРОВОГО МИСТЕЦТВА
}

У статті відслідковано традииї розвитку украӥнського хорового мистецтва від давніх часів до наших днів. Акиентовано увагу на психологічному розвитку диригента-хормейстера як очільника та наставника хорового колективу. Звернено увагу на причини непорозумінь $і$ конфліктів в хоровому колективі $i$ методи їх усунення, наголотено на важливій ролі вміння зберігати рівновагу $і$ душевний спокій в непростій, емоиійно насиченій роботі диригента-хормейстера, досліджено позитивний вплив мови-прім на покращення психологічного клімату в мистечькому колективі.

Ключові слова: хоровий колектив, свідомість, мова-прім, психологічна зрілість.

Лim. 7.

Svitlana Teodorovych, Lecturer of the Musicology and Choral Art Department Mykhaylo Kovbasyuk, Associate Professor of the Musicology and Choral Art Department Culture and Arts Faculty Lviv Ivan Franko National University

\section{PSYCHOLOGICAL MATURITY OF A CONDUCTORAND CHOIRMASTER AS AN IMPORTANT CONDITION OF PRESERVING UKRAINIAN CHOIR ART TRADITIONS}

The article studies the traditions of development of Ukrainian choral art from ancient times to present days. The article focuses on psychological development of a conductor and choirmaster as the supervisor and head of a choir. The special attention is paid to singing education which started in the period of ruling of Volodymyr and Yaroslav, spread in the middle Ages and led to the foundation of a court choir formed of the best singers in Ukraine in the 15th century. Then the origination and development of polyphonic singing is studied, and also partsong, cantus and psalms. The article emphasizes the role of Mykola Diletskiy who initiated the first theoretical works on development of singing voice and whose traditions were followed by well-known composers such as M. Berezovskiy, A. Vedel, D. Bortnyanskiy in their choral concertos. The transition from classicism to romanticism in Ukraine is also studied in the article, which was reflected in the works of famous composers M. Verbytskiy, I. Lavrivskiy, N. Nishchynskiy and others, and in the works of the founder of Ukrainian classical music M. Lysenko in particular. Further development of Ukrainian choral art is studied, which leading Ukrainian musicians L. Dychko, V. Zubytskiy, V. Kaminskiy and others pay attention to.

The article studies the psychological aspect of the work of a choral conductor, who directly realizes the 


\section{ПСИХОЛОГІЧНА ЗРІЛІСТЬ ДИРИГЕНТА-ХОРМЕЙСТЕРА ЯК ВАЖЛИВА ЗАПОРУКА ЗБЕРЕЖЕННЯ ТРАДИЦЙ УКРАЇНСЬКОГО ХОРОВОГО МИСТЕЦТВА}

ideas of well-known Ukrainian composers through the choir. The importance of constant and purposeful work of the conductor on psychological self-improvement is stressed, apart from purely professional skills and techniques. Based on the experience of contemporary psychologists and psychotherapists such as H. Erzhemskiy, N. Korykhalova, R. Dass, H. Braden and others the causes and possibilities of solving conflicts between the members of a choir are revealed; vision of these misunderstandings from the point of view of quantum psychology is regarded through works by $R$. Wilson, a philosopher and publicist, in particular. As an example of improving psychological climate within the choir the article studies the use of language-priming invented by British psychologists D. Bourland and A. Korzybskiy. Implementation of language-priming can be of great use for psychological health and balance of every person. Also the conclusion was made regarding the necessity of a modern creative artist who works with people and transmits to the audience the greatest works of Ukrainian choral music, who broadens their world outlook and remains in the constant spiritual search.

Keywords: a choir, consciousness, a language-priming, psychological maturity.

П остановка проблеми. В умовах українського сьогодення відбувається зростання інтересу до хорової музики, iii багатовічних традицій, глибинних пластів iї духовної культури.

В сучасному мистецькому житті України значно збільшилась чисельність хорових колективів, які гідно демонструють високий рівень хорової школи України як всередині країни, так і за кордоном. Особливої актуальності набуває зараз особистість хормейстера, його психологічна готовність до роботи $з$ колективом співаків.

Сьогоднішня практика хорової культури базується на диригентському типі хормейстерського професіоналізму, що $є$ досить багатофункціональним, адже передбачає інтерпретаційну, виконавчу, управлінську, репетиційну та організаторську діяльності. Але, як показує досвід, диригентухормейстеру, крім відповідних знань, умінь, навичок, безпосередньо пов'язаних із професійною діяльністю, необхідно володіти здатністю забезпечувати “поліфонію спілкування" у колективі, домагаючись міжособистісної сумісності 3 урахуванням індивідуальних особливостей учасників (віку, національної приналежності, характеру, темпераменту тощо). Отож, дослідницьку думку зосереджуємо на вивченні психологічних особливостей міжособистісних відносин диригента хормейстера та хорового колективу.

Аналіз останніх досліджень та публікацій. Проблеми психологічної підготовки диригентахормейстера розкриті доволі фрагментарно у публікаціях таких авторів як Г.Л. Ержемський, Н.П. Корихалова, Кім Ен Джу та кількох інших, тому задача зберігає свою актуальність, вимагає подальшого дослідження і розкриття.

Метою статті після невеликого екскурсу в історію розвитку хорового мистецтва України $\epsilon$ наголосити на тій великій відповідальності сучасних хормейстерів-педагогів за збереження, інтерпретацію i донесення до слухачів невичерпних скарбів високохудожніх хорових творів минулого, i, одночасно, ознайомлення всіх поціновувачів мистецтва 3 творчістю сучасних композиторів.

Виклад основного матеріалу дослідження. Хорова музика слов'ян бере свій початок у далекому минулому, і вона тісно пов'язана 3 культурою і побутом наших предків. Вона була невід'ємною частиною самого життя, супроводжувала усі події - як радісні, так і сумні. Особлива увага співочому вихованню приділялася в період князювання Володимира і Ярослава: почали друкувати перші співочі книги, в школах і монастирях викладався церковний спів.

В епоху Середньовіччя, коли церква була панівною культурною силою, мистецтво і релігія звертаються до духовного життя людини. Церковний спів акапелла збільшував пишність і величність церковного дійства, допомагав створити атмосферу емоційного настрою. Молитви у формі хорового співу робили прихожан активними учасниками релігійного культу.

3 часом в усіх прошарках суспільства почало розвиватися світське музикування, яке спиралося на народні традиції. В XV столітті в Україні 3'являються співацькі абетки, був заснований придворний хор із 35-ти кращих співаків країни, більшість з яких були вихідцями з України. У XVI столітті в Україні народжується багатоголосний спів, а згодом - партесний концерт, канти, псалми. У 1738 році в українському містечку Глухові була відкрита “Співоча школа", де отримали музичну освіту багато відомих українських музикантів, композиторів, співаків. Одним з них був Микола Ділецький, який в своїй праці "Мусікійська граматика" започаткував перші теоретичні позиції щодо розвитку співочого голосу. Його традиції були продовжені в творчості відомих композиторів-хоровиків М. Березовського, А. Веделя, Д. Бортнянського. Хорові концерти цих авторів - це одна із кульмінацій розвитку світового хорового мистецтва взагалі, вони наповнені глибоким роздумом та особливими якостями душевної відкритості.

Протягом всієї історії розвитку української музичної культури хорова музика посідала 


\section{ПСИХОЛОГІЧНА ЗРІЛІСТЬ ДИРИГЕНТА-ХОРМЕЙСТЕРА ЯК ВАЖЛИВА ЗАПОРУКА ЗБЕРЕЖЕННЯ ТРАДИЦЙ УКРАЇНСЬКОГО ХОРОВОГО МИСТЕЦТВА}

особливе місце в творчості більшості українських композиторів. В ХІХ столітті відбувається перехід від класицизмудо романтизму, який в Україні став формою національно-культурного відродження. Це знайшло своє відображення в хоровій творчості М. Вербицького, І. Лаврівського, П. Ніщинського, П. Сокальського, А. Вахнянина, А. Матюка, С. Воробкевича.

Видатний український композитор, основоположник української класичної музики М. Лисенко підсумував досягнення попередників і розпочав нову епоху в розвитку національної музичної культури. Його новаторство в галузі вокально-хорової музики це хорова пісня, мініатюра, поема, баркарола, кантата, духовні твори. Творчі і естетичні засади М. Лисенка, національний стиль його музики справили значний вплив на його послідовників -К. Стеценка, М. Леонтовича, Я. Степового, О. Кошиця, С. Людкевича, О. Нижанківського, Д. Січинського, Ф. Колессу і ін.

Історія розвитку хорового мистецтва свідчить про великі потенційні можливості впливу на духовний світ особистості, на пробудження енергетичних ресурсів кожної людини. Свій внесок у розвиток хорової культури зробила наступна плеяда відомих композиторів: А. КосАнатольський, Є. Козак, Г. Жуковський, Г. Майборода, І. Шамо, В. Кирейко, А. Коломієць, Б. Лятошинський і багато інших. Це час розквіту хорової мініатюри, яка була звернена до найпотаємніших сподівань і прагнень людської душі, і була фактором виховання людської індивідуальності.

В наш непростий 3 огляду на політичну i економічну ситуацію час сучасні українські митці своєю творчістю, зокрема, хоровими творами, палко відгукуються на запити сьогодення. Сучасна Україна потребує зміцнення сили i духовної величі іiі народу, і тому відроджуються іiі духовні традиції. Зокрема, високі естетичні засади давньої літургійної музики не могли залишити байдужими сучасних митців. I невдовзі визріла нова композиторська школа, яка стала послідовним продовжувачем історичної традиції української духовної музики. Серед ії представників - Л. Дичко. В. Зубицький, В. Камінський, В. Степурко, Ю. Алжнєв, О. Козаренко та інші талановиті музиканти.

Сьогодні завдяки дослідженням у галузях соціальної психології, психології праці, психології спілкування й колективної діяльності, психології творчості, музичної психології з'явилася можливість пояснити структуру функціонування психологічних механізмів, що складають основу професійної діяльності диригента-хормейстера [2].
Вивченню диригентських якостей, необхідних для ефективної роботи з колективом, присвячено дослідження Г. Адлера, В. Бондаренко, Г.Ержемского, Н. Корихалова, Н. Селезнева, Е. Шишова. та ін. У працях сучасних учених С.Гребенюка,М. Макаренка, I. Рожкова, Кім Ен Джу та ін. визначено комплекс професійних знань, інформаційної та інтелектуальної культури, що дає можливість створювати активне поле творчої взаємодії диригента та виконавця.

Специфіка структури диригентської діяльності хормейстера передбачає певні взаємовідносини в системі “диригент - хоровий колектив”, що включають психологічний, технічний та етикоестетичний аспекти. Психологічний аспект - це вплив диригента на хоровий колектив, який відбувається на раціональному та емоційному рівні. Диригент-хормейстер впливає на свідомість хористів за допомогою слів, на підсвідоме начало - за допомогою емоційного спілкування, магнетизму [4, 150].

Психологічні особливості диригентської діяльності обумовлені тим, що його “інструментом" $є$ колектив музикантів, який складається 3 безлічі особистостей із різним рівнем підготовки, різними характерами i темпераментами, а також різними психологічними особливостями.

Зрозуміло, що згідно зі своїм призначенням диригент проводить із колективом репетиції, керує виконанням, відповідно до свого розуміння змісту й різноманітних стилістичних особливостей дає творові своє художнє тлумачення, надихає й організовує виконавців, проявляє творчу індивідуальність, художню культуру, смак, темперамент, волю тощо [7, 3]. Однак, проявляючи волю, диригент мусить бути особливо обачним, аби “воля” i “підкорення” не зіпсували емоційної складової музичного твору основи основ музичного мистецтва, слідкувати, щоб під час роботи 3 колективом (особливо на сцені) не спостерігалося привнесення емоцій, які супроводжуються зверхністю, авторитаризмом і особливо насильством, що в одних виконавців викликає спротив, агресію й огиду, а у інших страх. Як наслідок - наявність негативної енергетики, що виражається у звуці наляканого, приниженого або ж агресивно налаштованого колективу. І чим швидше диригент це усвідомить, тим швидше у колективу з'явиться повага та довіра до свого керівника. Доброта, що йде від Маестро, його талант (бездоганний слух, музична пам'ять, метро-ритмічне чуття), ерудиція й інтелект здатні забезпечити диригентові небувалий успіх [3]. 


\section{ПСИХОЛОГІЧНА ЗРІЛІСТЬ ДИРИГЕНТА-ХОРМЕЙСТЕРА ЯК ВАЖЛИВА ЗАПОРУКА ЗБЕРЕЖЕННЯ ТРАДИЦЙ УКРАЇНСЬКОГО ХОРОВОГО МИСТЕЦТВА}

Перед сучасними диригентами-хормейстерами, окрім завдання суто професійних вмінь і навичок, стоїть завдання постійної і цілеспрямованої роботи над собою, маючи на меті неухильний ріст власної свідомості. Цій місії внутрішньої трансформації митця приділяли і приділяють увагу багато практикуючих психологів. Наприклад, сучасний американський психотерапевт Рам Дасс (справжнє його ім'я Річард Алперт) в поняття “свідомість” включає практично необмежені можливості людини, що потенційно існують в ній. Свідомість, не обмежена конвенціональною думкою, результатом якої є обмеження в часі і просторі, може в буквальному сенсі зсунути гору. "Робота над собою, - зауважує Рам Дасс, - є найвища річ, яку я взагалі можу зробити, тому що я зрозумів, що, якщо людина підвищує рівень своєї свідомості, вона бачить великі творчі можливості для вирішення проблеми, 3 якою вона перетинається" $[5,46]$.

Робота хорового диригента - це передусім робота 3 людьми, з творчим колективом професійним, самодіяльним, учбовим, в якому нерідко виникають непорозуміння, конфлікти як між учасниками, так і між керівником i учасниками. Причиною цього зазвичай $\epsilon$ неспівпадіння інтересів і цінностей людей, різний рівень розвитку свідомості і досить “завужене" бачення ситуації, яка викликає невдоволення. Ось як про це говорить сучасний письменник, філософ і публіцист Роберт Уілсон у своїй праці "Квантова психологія. Керування свідомістю": “Трансакційна психологія довела, що, всупереч багатовіковому “здоровому глузду”, людська свідомість приймає враження із зовнішнього світу не пасивно. Скоріше ми активно створюємо наші враження: із безлічі різноманітних сигналів мозок помічає ті, які ми сподіваємось побачити. А вже потім ми організовуємо ці сигнали у таку модель, чи такий тунель реальності, який найбільше узгоджується з нашою уявою про те, що “дійсно має місце в світі”. Конфлікт виникає через хибну думку, що мій тунель реальності - “виключно правильний”, коли мені доводиться мати справу 3 людиною, чий тунель реальності - також “виключно правильний” $[6,135]$.

Отже ми бачимо, наскільки важливо для очільника хорового колективу бути “миротворцем” цих різних “тунелей реальності” співаків, вміти опановувати свої емоції, подаючи приклад для підлеглих, змінювати і розширювати власний світогляд, власні погляди і звички. Цікаву думку 3 цього приводу висловлює американський психолог Грегг Брейден у своїй роботі
“Божественна матриця”: ”Якщо ми не задоволені чимось в оточуючому світі, то ми повинні звернути увагу на самих себе. Всі негативні ситуації, в яких ми опиняємося, - роздратування, що демонструють колеги, чи зрада зі сторони близьких людей, - результат наших власних неусвідомлюваних установок” $[1,175]$.

Для покращення психологічного клімату в колективі керівникові корисно буде оволодіти так званою мовою-прім, а також, за бажанням, ознайомити з нею своїх підопічних. Авторами цієї мови є Альфред Коржибський і Девід Борланд, які запропонували виключити 3 англійської мови “ідентифікаційне” дієслово “іs” (“є”), в результаті чого з'явилась мова, яку назвали мовою-прім. Цією мовою пропонується давати речам визначення в термінах людських операцій, а не неіснуючих сутностей, які, взагалі-то, є ярликами i необгрунтованими оцінками. Конкретна соціальна реальність визначається правилами, що прийняті в даній культурі, взаємодією індивідуальностей з обмеженою пропускною здатністю нервової системи суб' єкта. Сприйняття кожної людини містить в собі несвідомі упередження. Те, що є нормою для однієї людини, несприятливо для іншої. Мова-прім - це системний спосіб розв'язання протиріч між нашими “тунелями реальності”, нашою нездатністю описати світ повністю, нашою звичкою для спрощення визначати об'єкти оточуючого світу, що змінюються, як незмінні сугності. Аргументи в ділових суперечках, що не задовільняють багатьох опонентів, при перекладі на мову-прім часто набувають змісту і стають прийнятними. Наприклад, теза "Ваші методи роботи є тиранією” звучить як "Ваші методи роботи виглядають як тиранія, якщо дивитись на них моїми очима і з точки зору мого досвіду і знань". Мова-прім окреслює те, що відбувається в мозку того, хто говорить, і вказує на мозок як на інструмент, що здійснює оцінку. Люди, які вивчили мову-прім, обережні у своєму сприйнятті і не квапляться виносити судження, які протягом сторіч заганяли в глухий кут перемовини прихильників аристотелевої бінарної логіки.

Диригент, що оволодів мовою-прім у своїй повсякденній репетиційній роботі, ніколи не скаже такої, наприклад, фрази: “Тенори погано співають”. Його зауваження щодо звучання тенорової групи співаків звучатиме так: «В даний момент я сприймаю в звучанні тенорової партії деякі неточності, які, сподіваюсь, вони постараються виправити".

Оволодіння мовою-прім може принести велику користь для психічного здоров'я, томущо людина, 


\section{ПСИХОЛОГІЧНА ЗРІЛІСТЬ ДИРИГЕНТА-ХОРМЕЙСТЕРА ЯК ВАЖЛИВА ЗАПОРУКА ЗБЕРЕЖЕННЯ ТРАДИЦЙ УКРАЇНСЬКОГО ХОРОВОГО МИСТЕЦТВА}

сприймаючи ситуацію всебічно, з меншою імовірністю буде знаходитись у полоні суб'єктивної думки і вбереже нервову систему від емоційного перевантаження. Для керівника мистецького колективу, який складається із різних за своїми поглядами, уподобаннями i темпераментами особистостей, застосування мови-прім відкриває можливість розширити рамки сприйняття, дивитись на кожну людину 3 більшою терпимістю, розвивати культуру мислення і висловлювати думки в делікатній, толерантній манері і уникати непорозумінь та конфліктних ситуацій як з іншими, так і з собою.

Висновки. Працюючи над собою, розширяючи власні світоглядні горизонти, диригент, безумовно, свідомо і несвідомо впливає на колектив виконавців, яким керує, спонукаючи їх до внутрішніх психологічних змін. На репетиціях і концертних виступах встановлюється атмосфера довіри і взаємоповаги, зростає уважність і відповідальність кожного члена мистецького колективу за якість своєї роботи, i, врешті-решт, досягається головна мета - творче, натхненне i високохудожнє виконання хорових перлин, якими споконвіку так багата благодатна українська земля.

\section{ЛІТЕРАТУРА}

1. Брейден Грегг. Божественная матрииа / Перев. с англ. - М.: ООО Издательство "София", 2013. $-224 c$.

2. Ержемский Г. Л. Психология дирижирования: некоторые вопросы исполнительства й творческого взаимодействия дирижера с музыкальным коллективом / Г. Л. Ержемский. М.: Музыка, 1988. - 70 с.

3. Кім Ен Джу. Психологічні аспекти міжособистісних відносин у формуванні комунікативноїкомпетентності диригента / Кім Ен Дюу // Вісник МДУКМ. - 2008. - № 2 (22). C. 216-218.
4. Корыхалова Н. П. Интерпретация музыки. Л.: Музыка, 1979. - 243 с.

5. Рам Дасс. Это только танец. - Киев: София, 1994. $-120 c$.

6. Уилсон Роберт. Квантовая психология. Управление сознанием / Перев. с англ. - М.: ООО Книжное издательство "София", 2014. - 224 с.

7. Шишова Е. А. Психологічні особливості диригентської діяльності / Е. А. Шишова. Челябінськ, 2009.

\section{REFERENCES}

1. Braden, G. (2013). Bozhestvennaya matritsa [The Divine Matrix]. Moscow: Sofiya, 224 p. [in English].

2. Yerzhemskiy, G. L. (1988). Psikhologiya dirizhirovaniya: nekotorye voprosy ispolnitelstva $y$ tvorcheskogo vzaimodeystviya dirizhera $s$ muzykalnym kollektivom [Conducting psychology: some issues of performance and creative interaction of a conductor and a musical group]. Moscow: Muzyka, 70 p. [in Russian].

3. Kim En Dzhu (2008). Psykholohichni aspekty mizhosobystisnykh vidnosyn u formuvanni komunikatyvnoi kompetentnosti dyryhenta [Psychological aspects of interpersonal relationships in forming communicative competence of a conductor]. MDUKM Journal, vol. 2 (22), pp. 216 218. [in Ukrainian].

4. Korykhalova, N. P. (1979). Interpretatsiya muzyki [Interpretation of music]. Lviv: Muzyka, 243 p. [in Russian].

5. Dass, R. (1994). Eto tolko tanets [The only dance there is]. Kyiv: Sofiya, 120 p. [in English].

6. Wilson, R. (2014). Kvantovaya psikhologiya. Upravlenie soznaniem [Quantum psychology. Managing the mind]. Moscow: Sofiya, 224 p. [in English].

7. Shyshova, E. A. (2009). Psykholohichni osoblyvosti dyryhentskoi diialnosti [Psychological features of conductor's work]. Cheliabinsk. [in Russian].

Стаття надійшла до редакції 02.02.2018

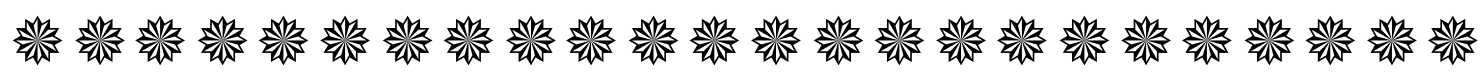
“Кожен великий успіх науки має свойм джерелом велику сміливість уяви". Dжон Dъюі американський білособ і педагог

"ТТри риси роблять з людини диво - $і$ ие вищі дари Верховної Жеедроти: плідний талант, глибокий розум, витончений $і$ щасливий смак”.

Бальтасар Трасіан-i-Моралес іспанський прозаїк

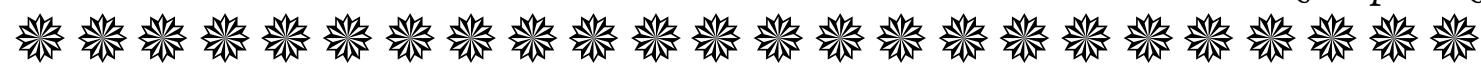

